Nippon Suisan Gakkaishi $\quad$ 60(6), 801-802 (1994)

シンポジウム 水産資源の音踣調查手法の現状と展望

\title{
ターゲットストレングスの推定法とその応用： 新技術を用いた直接推定法*1
}

\author{
澤 田浩 一*2
}

水迹工学研究所

自然状態の魚の正確なターゲットストレングス（以下 TS）を求めることは，重要であるが、従来の単一ビーム の魚群探知機では，送受波器の指向性に対する補正がで きないために困難であった。近年，広く使われるように なってきたデュアルビーム法、スプリットビーム法を用 いた計量魚群探知機は，ビームを工夫して，この指向性 の補正を行うために考えられたあのである。これらの方 法を発展させれば，魚の体長だけでなく，TSの傾角によ る特性や遊泳速度，遊泳方向等の行動を屯調べることが できる。なお，準理想ビーム法は別章で扱われるために ここでは述べない。

\section{測定原理}

デェアルビーム法の原理 デュアルビーム法では図 1(A)に示すように, 指向性の広いビームと狭いビーム を用い，狭ビームで送波したエコ一を広ビーム执よび狭 ビームで受波する。魚が中心から外机た位置にいた場 合, 広ピームと狭ビームではその指向性の違いにより受 波エコーにレベル差が生じる。このレベル差より，ビー ム中心からの角度がわかり、指向性の補正を行うことが でる。

スプリットビーム法の原理 スプリットビーム方式計 量魚群探知機は，エコーレベル測定用ビーム（レベル ビーム) と, 図1(B)に示すような2 組の位相測定用 ビーム対（位相ビーム）を用いる。レベルビームでレバ ルを測定し，位相ビーム対で反射対方向の角度を知り， それにより決まる指向性係数でエコーレベルを補正し て，魚などのターゲットストレングスを求める。

\section{直接法の実際}

魚のTS を測定するためには，返ってきたエコーの中 から单体エコーを検出する必要がある。一般にはパルス 偪を测定し，ある基準に収まるものを単体エコーとす る。スピリットビーム法ではさらに，位相のあばれにつ いても調べ，より精確に検出を行うことができる。検出 された单体エコーレベルに指向性補正を行い，較正など
で得られる既知のシステム感度で割ることによって精確 なTSを得ることができる。体長 $L$ と魚の姿勢について の平均 TS $の T_{\mathrm{S}(\mathrm{AVG})}$ との間には(1) 式に示す関係があ る。 3 , 4)

$$
T_{\mathrm{S}(\mathrm{AVG})}=T_{\mathrm{sem}} L^{2}
$$

$T_{\mathrm{scm}}$ は基準化 $\mathrm{TS}$ を表し魚種と周波数などによって決 まる值である。ほぼ，等しい体長からなる魚群について は，(1) 式で， $T_{\mathrm{Scm}}$ に適切な值を使用し，直接法で測定し た $T_{\text {S(AVG) }}$ より, 魚体長の推定汃可能となる。図 2 に開洋 丸に搭載されたスプリットビーム万式計量魚探機により 得られた，冬季のスケトウダラ魚群に対するTSの測定 結果を示す。縱軸は水深，横軸はTS を示している。例え ば，701 から800までのピングの間に，水深が 280 から $320 \mathrm{~m}$ の層で, 単体エコ一数は 508 であり, そのうち TS が $-36.0 \sim 33.0 \mathrm{~dB}$ の魚の分布密度が $126 \times 10^{-7} \mathrm{~m}^{-3}$ であることがわかる。またこの深度層での平均 TS は $-31.8 \mathrm{~dB}$ であり， $T_{\mathrm{scm}}$ としてスケトウダラについて妥 当とされている5 $-66.0 \mathrm{~dB}$ を使用した場合，推定体長 が $51.0 \mathrm{~cm}$ であることを示している。

単体ェコー検出の際には, ノイズスレッショルドを用 いて，ノイズレベル以下の信号をカットする。しかし，

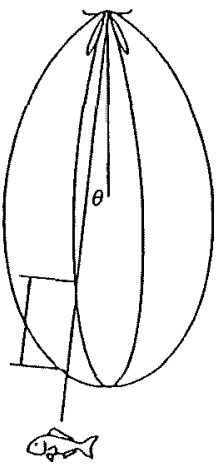

(A) デュアルビーム

*1 Target Strength Estimation in Situ by Direct Method.

*2 Kouichi Sawada (National Research Institute of Fisheries Engineering, Hasaki, Kashima, Ibaraki 314-04, Japan) 


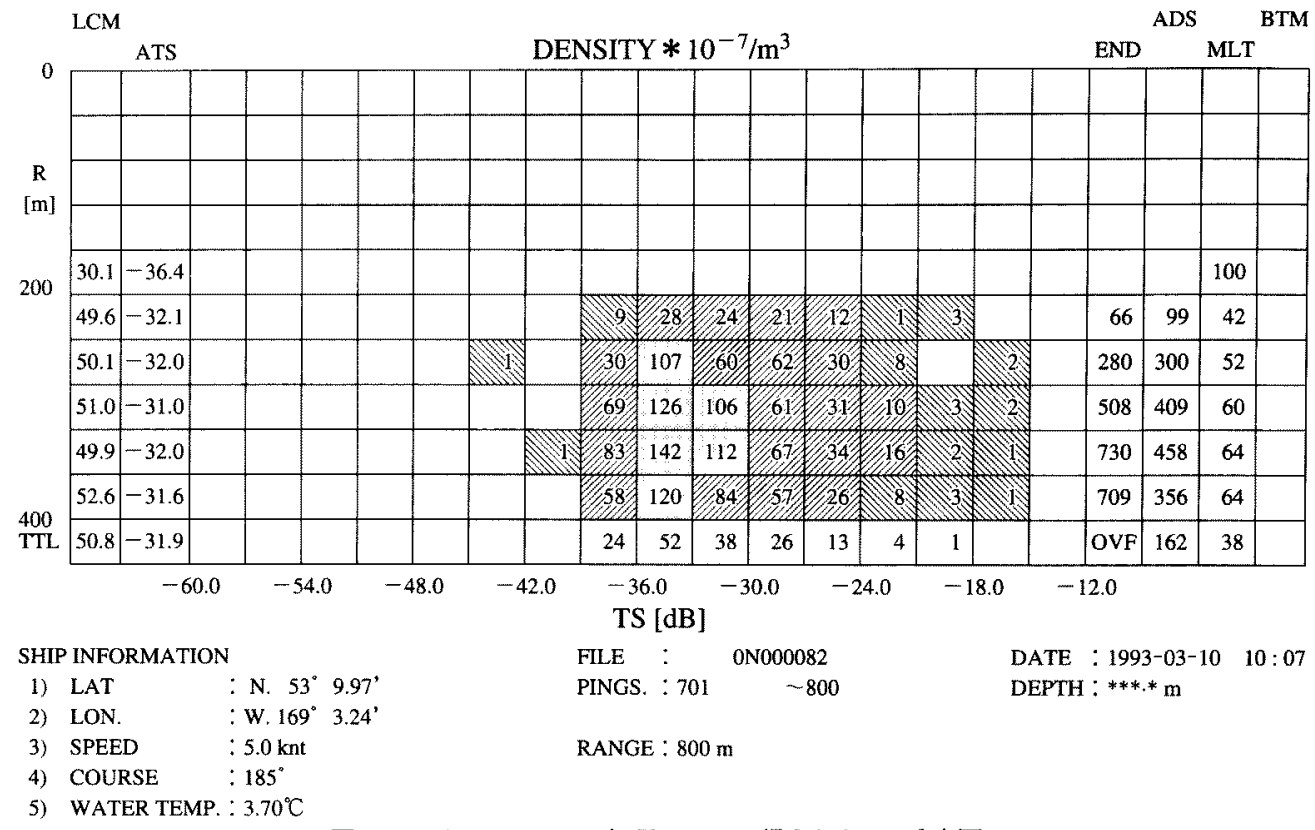

図 2 スプリットビーム好理によって得られたTS 分布図

必要以上にストレッショルドを高くすると，エコーも カットしてしまい，結果として測定したTS 分布は本来 の分布より高い万に偏ることになる。）TS は信号対雑音 比が大きい状態で測定すべきであり，ノイズスレッショ ルドはできるだけ低い方がよい。また，ビームの端では 信号対雑音比が小さいために，小さなTSは大きなTS に比へて検出されにくい。その結果平均 TS は大きい方 に偏ることになる。そこで，適切なビームの範囲内で TS 測定する必要がある。”さらに，魚の密度が高い時や深 いところにいる場合には群体エコーとなりやすい。この 結果，単体検出がうまくいかず精確な TS 测定ができな いので注意が必要である。

\section{今後の発展方向}

エコートレース解析法によって遊泳速度，遊泳方向な どの魚の行動だけでなく，TSパターンを知ることがで きる。9,10) スプリットビーム法では魚の位置を特定でき るために航走しながらでも，これが可能である。TSパ ターン中の最大 TSがわかるから, 自然状態にある個別 の魚の体長を推定できる。体長，行動，TS パターンの特 徵といった情報は魚種判別のための大きな一助となりう 更

\section{文献}

1) M. Furusawa, Y. Takao, K. Sawada, T. Okubo, and K. Yamatani: Versatile echo sounding system using dual beam. Nippon Suisan Gakkaishi, 59, 967-980 (1993).

2) J. E. Ehrenberg: Analysis of split beam bachscattering cross section estimation and single echo isolation techniques. Applied Physics Labratory, University of Washington, APL-WU 8108 (1981).

3) R. H. Love: Target strength of an individual fish at any aspect. J. Acoust. Soc. Am., 62, 1397-1403 (1977).

4) K. G. Foote: Fish target strengths for use in echo integrator surveys. J. Acoust. Soc. Am., 82, 981-987 (1987).

5) K. G. Foote and J. J. Traynor: Comparison of walleye pollock target strength estimates determined from in situ measurements and calculations based on swimbladder form. $J$. Acoust. Soc. Am. 83, 9-17 (1987).

6) R. T. Weimer and J. E. Ehrenberg: Analysis of thresholdinduced bias inherent in acoustic scattering, cross section estimates of individual fish. J. Fish. Res. Board Can., 32, 2547-2551 (1975).

7) J. J. Traynor and N. J. Williamson: Target strength measurements of walleye pollock (Theragra chalcogramma) and a simulation study of the dual beam method. FAO Fisheries Rept., 300, 112-124 (1983).

8) K. Sawada, M. Furusawa, and N. J. Williamson: Conditions for the precise measurement of fish target strength in situ. $J$. Marine. Aoust. Soc. Jpn., 20, 73-79 (1993).

9) M. Furusawa and Y. Miyanohana: Application of echo-trace analysis to estimate of behaviour and target surength of fish. J. Acoust. Soc. Jph. (E), 9, 169-180 (1988).

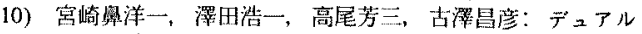
ビーム法によって目然遊泳魚から得られたエコートレー 又解析，日水锫，59,943-950 (1993). 